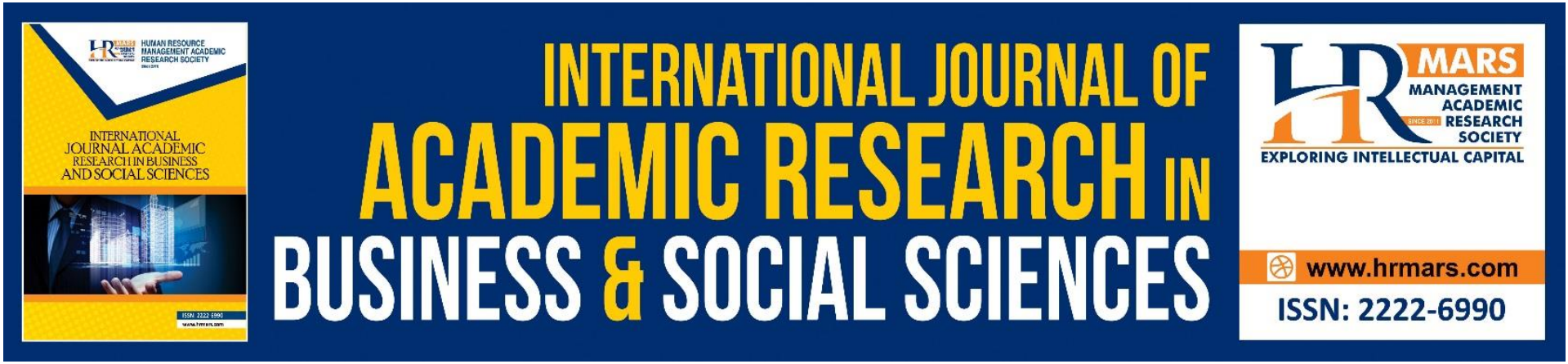

\title{
Waqf Bank Discussion Series: An Operational Structure Development for Economic Growth in Malaysia
}

Mohd Asyraf Yusof, Surita Hartini Mat Hassan, Mohamad Sahizam Musa, M. Nasrul Hakim Roslan, Mohd Nasir Ayub

To Link this Article: http://dx.doi.org/10.6007/IJARBSS/v12-i1/12349

DOI:10.6007/IJARBSS/v12-i1/12349

Received: 17 November 2021, Revised: 20 December 2021, Accepted: 08 January 2022

Published Online: 29 January 2022

In-Text Citation: (Yusof et al., 2022)

To Cite this Article: Yusof, M. A., Hassan, S. H. M., Musa, M. S., Roslan, M. N. H., \& Ayub, M. N. (2022). Waqf Bank Discussion Series: An Operational Structure Development for Economic Growth in Malaysia. International Journal of Academic Research in Business and Social Sciences, 12(1), 2698-2707.

Copyright: @ 2022 The Author(s)

Published by Human Resource Management Academic Research Society (www.hrmars.com)

This article is published under the Creative Commons Attribution (CC BY 4.0) license. Anyone may reproduce, distribute, translate and create derivative works of this article (for both commercial and non0-commercial purposes), subject to full attribution to the original publication and authors. The full terms of this license may be seen at: http://creativecommons.org/licences/by/4.0/legalcode

Vol. 12, No. 1, 2022, Pg. $2698-2707$

Full Terms \& Conditions of access and use can be found at http://hrmars.com/index.php/pages/detail/publication-ethics 


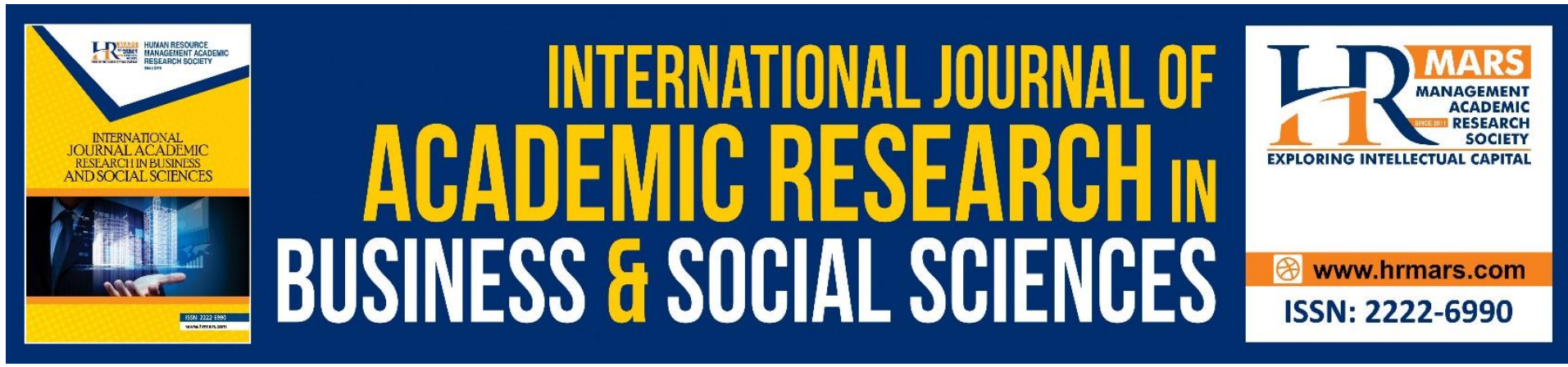

\title{
Waqf Bank Discussion Series: An Operational Structure Development for Economic Growth in Malaysia
}

\author{
Mohd Asyraf Yusof, Surita Hartini Mat Hassan \\ Akademi Pengajian Islam Kontemporari, Universiti Teknologi MARA, Cawangan Pahang \\ Kampus Raub, Raub, Pahang \\ Mohamad Sahizam Musa \\ Fakulti Sains Pentadbiran \& Pengajian Polisi, Universiti Teknologi MARA, Cawangan Pahang \\ Kampus Raub, Raub, Pahang
}

M. Nasrul Hakim Roslan, Mohd Nasir Ayub

Akademi Pengajian Islam Kontemporari, Universiti Teknologi MARA, Cawangan Pahang

Kampus Raub, Raub, Pahang

\begin{abstract}
Waqf is an Islamic financial mechanism that can improve the quality of the Islamic financial system. The Islamic banking system's operation using waqf practices such as creating waqf banks (WB) can contribute to the development of the Islamic financial and economic system. However, until now, Malaysia still does not have a WB. In line with this, the main objective of this study is to propose a model that focuses on how to develop the new WB Operational Structural model, which has to be in line with shariah law. This study is a qualitative study using an exploratory design. This study involved the collection of primary and secondary data. Primary data were obtained through face-to-face interviews using semi-structured questions on waqf institutions executives, Islamic bank managers, and Muslim scholars to indicate WB operational structure development. Secondary data involves document sources such as books, magazines, journals, and others. The data were then analyzed by qualitative content analysis. The study results found that the bank endowment structure model should consist of the consumer banking department ( $C n B D)$, corporate banking department (CBD), and the bancassurance department. It is hoped that this bank wakaf model can be used as a guide for banks and national leaders in their efforts to develop a wakaf bank in Malaysia.
\end{abstract}

Keywords: Waqf, Waqf Bank, Waqf Bank Operational Structure, Structure Development, Economic Growth.

\section{Introduction}

WB has not been established yet in Malaysia. The need to develop this kind of bank is intensifying due to the current Malaysian economic condition (Ab Aziz, 2014a; Yusof, 
Ridhwan, et al., 2013; Yusof \& Ab. Aziz, 2015), especially during this pandemic Covid-19. Most Malaysian lost their job because of the economic downturn. Thus, this research aimed to develop WB Operational Structure for Malaysia's economic growth. This research tries to merge the function of waqf institution, Islamic bank institution and takaful institution for improving Malaysian standard of living.

Economic growth can be defined as expanding economic development by improving factors such as domestic and international policies, working conditions, health, education, and market environments in developing nations. It reviews both macroeconomic and microeconomic factors relating to the structure of a nation's expanding economy and in what way it can yield adequate domestic and international economic improvement (Philippe et al., 2009).

Other than that, the amalgamation between waqf institution and Islamic financial institution which is a generosity based institution supposed to be the best solution for acquiring financial stability due to the landscape of these two financial institutions (Hachicha \& Ben, 2015; Rawashdeh et al., 2017; Dusuki, 2008). This study, however, will focus on how to develop the new WB Operational Structural model which has to be in line with shariah law.

\section{Literature Review}

WB operational structure's systematic search has been performed based on the keywords *waqf*, *waqf bank* and *waqf bank operational structure*. The searching process was done by using six databases: Sage Journals, Wiley Online Library, EBSCOhost, Science Direct, Scopus, and Emerald Premium. As a result of the search, 78 hits (articles) are found, and only 15 articles were selected due to the related field of study.

Study shows that waqf institutions can empower Muslims' economic development (Darus et al., 2017; Mahat et al., 2015). Apart from that, the combination between Islamic financial institution and waqf institution, which is a philanthropy based institution said to be the best solution for acquiring financial stability due to the nature of these two financial institutions (Hachicha \& Ben, 2015; Rawashdeh et al., 2017; Dusuki, 2008). According to Chowdhury et al. (2011), cash waqf will also aid in the reform of the current institutional setup and their networking relationships across the region, with the goal of improving their efficiency in the direction of effective and need-based dynamic management of waqaf affairs.

On the other hand, cash waqf investment through the mudharabah contract is permissible in Islamic law. WB can apply this cash waqf investment practice as financial aids intended for the poor ( Ab.Aziz \& Yusof, 2014b; Ridhwan et al., 2017).

First, WB can disburse the ROI from cash waqf investment, dedicated to financial aids to the poor. The invested cash waqf can be perpetual as it is in line with waqf rulings. As a rule, productive waqf must be kept invested and an income-generating investment vehicle, which can be better in the banking system (Mohammad, 2011a; Mohammad, 2011b; Yusof, Ab. Aziz, et al., 2013). Today's Islamic banking activities prove that cash investment success is assured. The core characteristic of waqfs, such as perpetuity of the object or the capability of recurrent use and benefit, would apply to both the cash waqf and WB alike (Ab. Aziz \& Yusof, 2019; Yusof \& Ab. Aziz, 2015).

The development of the WB operational structure as social welfare is needed in this century. Looking at the unsustainable economic growth, current banking systems, including Islamic banks, prove that this system cannot assist society. The gap between the rich and the poor is going wider. Inequality of income, the concentration of wealth in $20 \%$ of the global 
population, the high level of poverty in Muslim and other developing countries, and the increase in the number of older people in advanced society make a social bank's need urgent more than ever. The proposed WB can help the state provide decent living standards to its citizens, including shelter, education, healthcare, employment, and the like (Ridhwan, Aziz, \& Yusof, 2014; Yusof, et al., 2014; Ridhwan, et al., 2013)All paragraphs must be indented.

\section{Methodology}

This paper applied qualitative research methods and exploratory research design in a comprehensive study. This research has a conceptual framework that overlays the semistructured interviews, the study's data collection method. Semi-structure interviews were conducted with waqf institutions executive, Islamic bank manager and Muslim scholars to indicate WB operational structure development and continue until this study meets its saturation point.

Emails and messages were sent via online social media such as Facebook, Twitter and Gmail to the interviewee before the interview session started. This medium will give the interviewee a general idea regarding the interview context and prepare some relevant answer. Interviewees are only selected if they are an employee of waqf institutions, Islamic bank institutions and Muslims scholars. The data were then analyzed by qualitative content analysis.

\section{Discussion and Findings The WB Operational Structure}

This paper will briefly explain the WB operation team. To understand this subject matter, the researcher will briefly explain the operation team's component: consumer banking department ( $\mathrm{CnBD})$, corporate banking department (CBD), and bancassurance department.

\section{Waqf Bank Consumer Banking Department}

Services provided by the CnBD include saving and current accounts, mortgages, debit card, credit card, personal loan, and deposit certificate (Fan et al., 2018). CnBD is also known as the retail banking department that provides financial services for a consumer (Mullineux, 2009). This department's most important function is providing deposit, money management, and credit service to the customer (Patro, 2013).

This department provides extra liquidity to the consumer and the economy (Ali et al., 2014). This excess liquidity or extra credit allows the consumer to spend their future earnings at the present (Çokgezen \& Kuran, 2015; Griffin et al., 2018). On the other hand, small and medium enterprises (SME) use this opportunity to expand their business since they have extra buying power (Tumwine et al., 2015). 


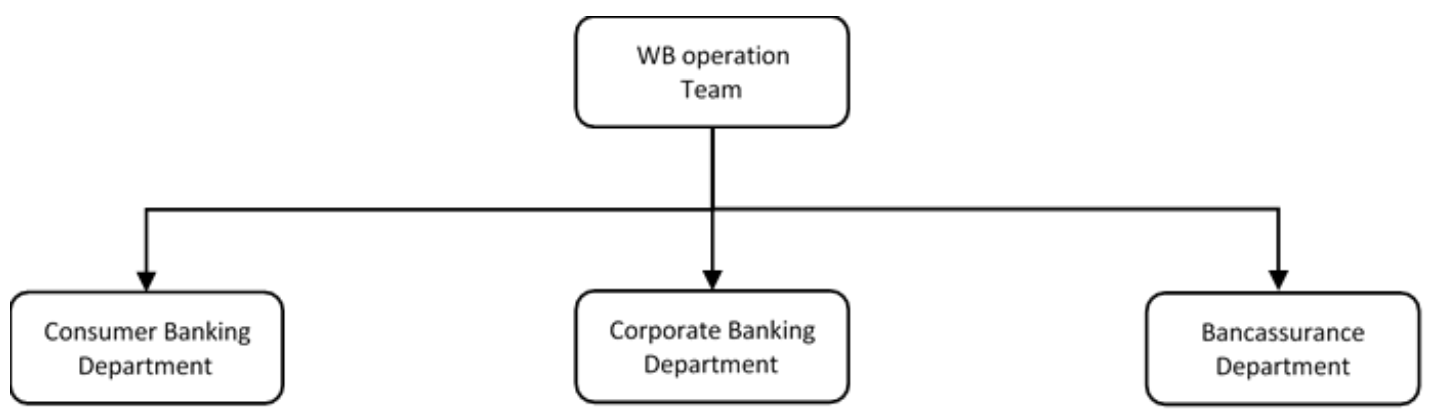

\section{Figure 1. WB Operational Structure Source: Developed for the Current Study}

In Malaysia, all Islamic banking does have this department, and they do provide service as mention earlier, and this department operates in line with shariah law (Khan et al., 2008; Mushtaq \& Siddiqui, 2016; Sufian \& Zulkhibri, 2015; Zulkhibri, 2018). The service provided by the consumer department was not limited to Muslim consumer; this department also serves non-Muslim consumer (Mahdzan et al., 2017).

There were several advantages of $\mathrm{CnBD}$ stated in the literature. For instance, the CnBD provides a stable deposit, and safekeeping to the customer and this deposit was protected by insurance (Isazade, 2009; Kleftouri, 2014). Furthermore, the conventional bank retail banking department was insensitive to the interest charge to their consumer. This mean, there was no bargaining for a discount or additional interest (Corvoisier, Sandrine; Gropp, 2002; Williams \& Prather, 2010).

Islamic bank and conventional bank CnBD function as fund provider to the bank, resulting from customer deposits (Hamza \& Saadaoui, 2013). From this department, the bank can improve the economy or help revival the economy by providing a fund to an entrepreneur through the corporate banking department (Iqbal et al., 2018). Thus, this action will increase the nation's productivity (Repousis, 2015).

In contrast, a few disadvantages of $\mathrm{CnBD}$ reported in the literature. One of the disadvantages of this department was monitoring the massive financing, such as house financing, car financing and personal financing needs. Thus, banks have to spend heavily on human resource and salary expenses (IImi, 2018; Balfour et al., 2015). Besides that, long term financing such as house financing in the absence of proper follow-up can be non-performing financing due to its long term repayment contract (Bandyopadhyay \& Saha, 2011; Mohd Isa et al., 2018).

\section{Corporate Banking Department}

The CBD can be defined as a specialized department of a commercial bank that offers numerous banking services such as cash management, assets management credit management, and underwriting to large companies and SMEs. This department will assign specialized finance professionals who will help corporations achieve their business target (Abeysekera, 2011). This department is one of the bank primary sources of profit where this profit came from financing large corporation and SMEs (Abe et al., 2015; Narteh, 2013; Hussain et al., 2006). 
The difference between $\mathrm{CnBD}$ from $\mathrm{CBD}$ is that $\mathrm{CnBD}$ provides loan and financing to the consumer while CBD provides loan and financing to a large corporation (Jing-bo \& Ke-ke, 2011). The product that the corporate banking department provides to their corporate customers includes trade finance such as letters of credit, employer services such as payroll services, treasury services, loans and credit. Some banks provide internet banking services to their corporate customers (Chhina, 2016; Went, 2003).

Besides that, CBD provides a corporate account for institutional customer. This corporate account refers to an account specifically for SMEs, large corporations, and offshore business, which means this corporate banking department provides services specializing for business entities. Institutional customer is a term for a corporate customer which differentiate between retail customers and corporate customers (Proença \& Castro, 2000).

The targeted customer for CBD was different from CnBD. CBD usually target various industries such as automotive, healthcare, food and beverage, energy servicing, mining, utility companies, etc. (Thunman, 1992). In the WB corporate banking department context, the researcher could use this literature as a guideline for setting up this department.

\section{Bancassurance Department}

Bancassurance department function as a bridge between an insurance company and the bank. This department aimed to offer an insurance product to the bank's customer. The insurance company will earn a commission from the bank staff's insurance, while the bank will earn fee-based income from this transaction. This partnership between banks and insurance company will be profitable for both parties (Bergendahl, 1995).

Bancassurance department distributes insurance product to the consumer by specialized wealth advisers which they were the bank staff. The life insurance product is usually a medium and long-term investment product. This product was designed specifically for the bancassurance department to meet consumer needs in terms of matching and simplicity with banking products (Paul, 2012).

By having the bancassurance department, banks will have the potential to be multi-insurance distributors which offer various type of products from different insurance companies. This will ease the bancassurance department to meet its customers' needs, thus strengthening the department's position and the banks. The business model of bancassurance will affect all aspects of the banks' activity including the banks' structure, product design, sale and marketing, etc. (Htay et al., 2015).

Bancassurance department function as an efficient distributor with potentially higher sales with a lower cost of operation. These advantages were well connected to the degree of combining the banking and insurance product. However, there was no such proof presenting the exact range of the connection between the two (Deol, 2009).

In WB studies, the researcher suggested the integration of the Islamic banking structure with the waqf institution structure. This bancassurance department has shown the researcher the integrated models between bank and insurance companies. The researcher can learn a few 
things from these integrated models to develop the WB structure, at least for WB Bancassurance department development.

\section{Conclusion and Recommendation}

This paper aimed to establish the WB operational structure model for Malaysia's economic growth. These have led this paper to study various knowledge fields to fulfil in the academic world. These fields include waqf, cash waqf, corporate cash waqf, corporate cash waqf structure, WB operational team, Islamic banking, WB structure, etc. In addition, Waqf can form a mechanisme of savings-investment system in which funds are diverted from consumption and invested in productive assets that generate income.

Further study in the areas of WB is indeed essential to endeavour. The establishment of WB will need additional post-study research for it to be successful. Other areas requiring further studies are the legal aspects of banking practice and cash waqf funds for Muslim economic development. Due to cash waqf's potential in developing WB Organization in Malaysia, the study of the WB act should be the number one priority.

\section{Corresponding Author}

Name: Surita Hartini Mat Hassan

Affiliation \& Adress: Akademi Pengajian Islam Kontemporari, Universiti Teknologi MARA, Cawangan Pahang, Kampus Raub, 27600 Raub, Pahang.

Email: suritahartini@uitm.edu.my

\section{References}

Ab. Aziz, M. R., \& Yusof, M. A. (2019). Deposit and Financing Instruments Through Waqf Bank for Fostering Real Economy and Social Sustainability. International Journal of Islamic Business Ethics, 4(2), 611. https://doi.org/10.30659/ijibe.4.2.611-626

Ab. Aziz, M. R. A., \& Yusof, M. A. (2014). Tendency Among Public And Students For The Establishment of Islamic Waqf Bank. Seminar Waqf Iqlimi 2014, 593-602. http://ddms.usim.edu.my/handle/123456789/9903

Ab. Aziz, M. R. A., \& Yusof, M. A. (2014). Examining the Relationship between Level of Income and Appointment of Agent in Collecting Waqf Fund. International Journal of Trade, Economics and Finance, 5(2), 167.

Abe, M., Troilo, M., Batsaikhan, O., \& Abe, M. (2015). Financing small and medium enterprises in Asia and the Pacific. Journal of Entrepreneurship and Public Policy, 4(1), 2-32. https://doi.org/10.1108/JEPP-07-2012-0036

Abeysekera, N. (2011). Relationship Marketing Perspective on Salespersons Transformational Leadership Behavior Effect. Contemporary Management Research, 7(2), 143-156.

Ali, P., Ramsay, I., \& Read, C. (2014a). Behavioural Law and Economics: Regulatory Reform of Consumer Credit and Consumer Financial Services. Ssrn, 43, 298-343. https://doi.org/10.2139/ssrn.2524131

Aziz, M. R. A., \& Yusof, M. A. (2014b). Examining the Relationship between Level of Income and Appointment of Agent in Collecting Waqf Fund. International Journal of Trade, Economics and Finance, 5(2), 167-169. https://doi.org/10.7763/IJTEF.2014.V5.363

IImi, M. B. (2018). The analysis of the effect of Islamic financing and labor relationship development toward nonperforming financing in Islamic banks. Journal of Islamic 
Accounting and Business Research, 9(4), 648-660. https://doi.org/10.1108/JIABR-022015-0002

Balfour, R., Joo, S. J., Whited, H. hui I. H., \& Lin, J. W. (2015). Assessing the comparative performance of banking branches. Benchmarking, 22(5), 963-972.

https://doi.org/10.1108/BIJ-04-2013-0048

Bandyopadhyay, A., \& Saha, A. (2011). Distinctive demand and risk characteristics of residential housing loan market in India. Journal of Economic Studies, 38(6), 703-724. https://doi.org/10.1108/01443581111177402

Bergendahl, G. (1995). The profitability of bancassurance for European banks. International Journal of Bank Marketing, 13(1), 17-28.

Chhina, R. K. (2016). Managing money laundering risks in commercial letters of credit Are banks in danger of non-compliance ? Journal of Money Laundering Control, 19(2), 158168. https://doi.org/10.1108/JMLC-05-2015-0019

Chowdhury, M. S. R., Ghazali, M. F., \& Ibrahi, M. F. (2011). Economics of cash waqf management in Malaysia : A proposed cash waqf model for practitioners and future researchers. African Journal of Business Management, 5(30), 12155-12163.

Çokgezen, M., \& Kuran, T. (2015). Between consumer demand and Islamic law: The evolution of Islamic credit cards in Turkey. Journal of Comparative Economics, 43(4), 862-882. https://doi.org/10.1016/j.jce.2015.07.005

Corvoisier, Sandrine; Gropp, R. (2002). CENTRAL AND RETAIL INTEREST RATES. Journal of Banking \& Finance, 26(11), 2115-2189.

Darus, F., Shukri, A. N. H., Yusoff, H., Ramli, A., Zain, M., \& Abu Bakar, N. A. (2017). Empowering social responsibility of Islamic organizations through Waqf. Research in International Business and Finance, 42(July), 959-965.

https://doi.org/10.1016/j.ribaf.2017.07.030

Deol, H. S. (2009). Strategic environment and intellectual capital of Indian banks. Journal of Intellectual Capital, 10(1), 109-120. https://doi.org/10.1108/14691930910922932

Dusuki, A. W. (2008). Banking for the poor: The role of Islamic banking in microfinance initiatives. Humanomics, 24(1), 49-66. https://doi.org/10.1108/08288660810851469

Fan, B., Ji, H., Wei, J., \& Lambert, S. (2018). Development of tactical solutions for the e-credit card issuing industry. International Journal of Accounting and Information Management, 26(1), 115-131. https://doi.org/10.1108/IJAIM-02-2017-0014

Griffin, P. A., Hong, H. A., \& Ryou, J. W. (2018). Corporate innovative efficiency: Evidence of effects on credit ratings. Journal of Corporate Finance, 51(May), 352-373. https://doi.org/10.1016/j.jcorpfin.2018.06.007

Hachicha, N., \& Ben Amar, A. (2015). Does Islamic bank financing contribute to economic growth? The Malaysian case. International Journal of Islamic and Middle Eastern Finance and Management, 8(3), 349-368. https://doi.org/10.1108/IMEFM-07-2014-0063

Hamza, H., \& Saadaoui, Z. (2013). Investment deposits, risk-taking and capital decisions in Islamic banks. Studies in Economics and Finance, 30(3), 244-265. https://doi.org/10.1108/SEF-Feb-2012-0016

Htay, S. N. N., Sadzali, N. S., \& Amin, H. (2015). An analysis of the viability of micro health takaful in Malaysia. Qualitative Research in Financial Markets, 7(1), 37-71. https://doi.org/10.1108/QRFM-09-2013-0030

Hussain, J., Millman, C., Matlay, H., Hussain, J., Millman, C., \& Matlay, H. (2006). SME financing in the UK and in China: a comparative perspective. Journal of Small Business and Enterprise Development, 13(4), 584-599. https://doi.org/10.1108/14626000610705769 
Iqbal, M., Nisha, N., \& Rashid, M. (2018). Bank selection criteria and satisfaction of retail customers of Islamic banks in Bangladesh. International Journal of Bank Marketing, 36(5), 931-946. https://doi.org/10.1108/IJBM-01-2017-0007

Isazade, A. R. (2009). Azerbaijan: Deposit insurance system. Journal of Financial Regulation and Compliance, 17(3), 318-335. https://doi.org/10.1108/13581980910972250

Jing-bo, S., \& Ke-ke, C. (2011). Procedia Engineering Research on the measurement of customer equity of corporate banking business. Procedia Engineering, 15(2011), 47904794. https://doi.org/10.1016/j.proeng.2011.08.895

Khan, M. S. N., Hassan, M. K., \& Shahid, A. I. (2008). Banking Behavior of Islamic Bank Customers in Bangladesh. Journal of Islamic Economics, Banking and Finance, 3(2), 159194. https://doi.org/10.1108/17538390810901131

Kleftouri, N. (2014). Meeting the rationale of deposit protection system. Journal of Financial Regulation and Compliance, 22(4), 300-317. https://doi.org/10.1108/JFRC-03-20130009

Mahat, M. A., Jaaffar, M. Y., \& Rasool, M. S. A. (2015). Potential of Micro-Waqf as an Inclusive Strategy for Development of a Nation. Procedia Economics and Finance, 31(15), 294302. https://doi.org/10.1016/S2212-5671(15)01193-4

Mahdzan, N. S., Zainudin, R., \& Au, S. F. (2017). The adoption of Islamic banking services in Malaysia. Journal of Islamic Marketing, 8(3), 496-512. https://doi.org/10.1108/JIMA-082015-0064

Mohammad, M. T. S. (2011a). Towards an Islamic Social (Waqf) Bank. International Journal of Trade, Economics and Finance, January 2011, 381-386.

https://doi.org/10.7763/ijtef.2011.v2.135

Mohammad, M.T.S. (2011b). Permissibility Of Establishing Waqf Bank In Islamic Law. 2010 International Conference on Sociality and Economics Development, 10(Icsep), 250-254.

Mohd Isa, M. Y., Voon Choong, Y., Yong Gun Fie, D., \& Abdul Rashid, M. Z. H. (2018). Determinants of loan loss provisions of commercial banks in Malaysia. Journal of Financial Reporting and Accounting, 16(1), 24-48. https://doi.org/10.1108/JFRA-032015-0044

Mullineux, A. (2009). The regulation of British retail banking utilities. Journal of Financial Regulation and Compliance, 17(4), 453-466.

https://doi.org/10.1108/13581980911004406

Mushtaq, S., \& Siddiqui, D. A. (2016). Effect of interest rate on economic performance: evidence from Islamic and non-Islamic economies. Financial Innovation, 2(1), 9. https://doi.org/10.1186/s40854-016-0028-7

Narteh, B. (2013). SME bank selection and patronage behaviour in the Ghanaian banking industry. Management Research Review, 36(11), 1061-1080.

https://doi.org/10.1108/MRR-06-2012-0147

Patro, S. (2013). ICICl Bank: Brand Building in Retail Banking. Management and Labour Studies, 38(3), 277-295. https://doi.org/10.1177/0258042X13509748

Paul Cavelaars, J. P. (2012). Follow the money What does the literature on banking. Journal of Financial Regulation and Compliance, 20(4), 402-416.

https://doi.org/10.1108/13581981211279354

Philippe, A., Philippe, B., \& Romain, R. (2009). Exchange Rate Volatility and Productivity Growth: The Role of Financial Development. Journal of Monetary Economics, 56(4), 494513.

Proença, J. F., \& Castro, L. M. De. (2000). Cross boundary relationships in Portuguese banking 
and corporate financial services. International Journal of Bank Marketing, 18(7), 338346.

Rawashdeh, O. H., Azid, T., \& Qureshi, M. A. (2017). Philanthropy, markets, and Islamic financial institutions: a new paradigm. Humanomics, 33(4), 563-578. https://doi.org/10.1108/H-08-2016-0063

Repousis, S. (2015). Regulatory framework and deposit - investment guarantee fund in Greece. Journal of Financial Regulation and Compliance, 23(1), 18-30. https://doi.org/10.1108/JFRC-07-2013-0023

Ridhwan, M., Aziz, A., \& Yusof, M. A. (2014). An Initial Study on Student's Need towards Islamic Waqf Bank for Education. International Conference on Arts, Economics and Management (ICAEM'14), March 22-23, 71-74.

https://doi.org/10.15242/icehm.ed0314027

Ridhwan, M., Aziz, A., Yusof, M. A., \& Johari, F. (2014). Proclivity Among Students for the Establishment of Islamic Waqf Bank. International Conference on Business, Sociology and Applied Sciences (ICBSAS'14), 36-39. https://doi.org/10.15242/icehm.ed0314533

Ridhwan, M., Aziz, A., Yusof, M. A., Johari, F., Ramli, A., \& Sabri, H. (2017). The Relief of Higher Education Loan through Islamic Waqf Bank. Asian Social Science, 10(22), 175-181. https://doi.org/10.5539/ass.v10n22p175

Sufian, F., \& Zulkhibri, M. (2015). The Nexus between Economic Freedom and Islamic Bank Profitability in the MENA Banking Sectors. Global Business Review, 16, 58-81. https://doi.org/10.1177/0972150915601256

Thunman, C. G. (1992). Corporate Banking: Services and. International Journal of Bank Marketing, 10(2), 10-16.

Tumwine, S., Akisimire, R., Kamukama, N., \& Mutaremwa, G. (2015). A borrowing cost model for effective performance of SMEs in Uganda. World Journal of Entrepreneurship, Management and Sustainable Development, 11(2), 74-89.

https://doi.org/10.1108/WJEMSD-03-2014-0009

Went, P. (2003). A quantitative analysis of qualitative arguments in a bank merger. International Review of Financial Analysis, 12(2003), 379-403. https://doi.org/10.1016/S1057-5219(03)00031-0

Williams, B., \& Prather, L. (2010). Bank risk and return: The impact of bank non-interest income. International Journal of Managerial Finance, 6(3), 220-244. https://doi.org/10.1108/17439131011056233

Yusof, M. A., \& Ab. Aziz, M. R. (2015). Scrutinizing the Method of Contribution for Islamic Waqf Bank Fund. Journal of Islamic Economics Banking and Finance, 11(1), 181-192. https://doi.org/10.12816/0026024

Yusof, M. A., Ab. Aziz, M. R., \& Johari, F. (2013). The Relationship Between Level of Income and Willingness of Muslim Community To Contribute for Islamic Waqf Bank. 5th Islamic Economics System Conference (IECONS 2013), "Sustainable Development Through The Islamic Economics System", Organized, September, 4-5.

Yusof, M. A., Ridhwan, M., Aziz, A., \& Ramli, Y. (2013). EXPLORING NEW OPPORTUNITY AND MECHANISM FOR ISLAMIC WAQF BANK MODEL. 2nd Applied International Business Conference (AIBC2013), 805-816.

Zulkhibri, M. (2018). The impact of monetary policy on Islamic bank financing: bank-level evidence from Malaysia. Journal of Economics, Finance and Administrative Science, JEFAS-01-2018-0011. https://doi.org/10.1108/JEFAS-01-2018-0011 